\title{
AGRICULTURAL EDUCATION: INVESTING BASIC AGRI-FOOD EDUCATION AND AGRIPRENEURSHIP KNOWLEDGE TO EARLY AGE STUDENTS
}

\author{
Sujarwo $^{1}$, Dian Islami $\mathrm{P}^{1}$, Yusri Fajar ${ }^{2}$, Edlyn Khurotul Aini ${ }^{3}$, Anisa Aprilia ${ }^{1}$, \\ Putri Budi Setyowati ${ }^{1}$, Fitrotul Laili ${ }^{1 *}$
}

${ }^{1}$ Faculty of Agriculture, University of Brawijaya

${ }^{2}$ Faculty of Cultural Studies, University of Brawijaya

${ }^{3}$ Faculty of Administrative Science, University of Brawijaya

*corresponding author: laili@ub.ac.id

\begin{abstract}
The disinterest of the young generation in agriculture carries out awareness in providing agricultural education from an early age. Agri-food education and agripreneurship can be solutions to awake the youth's awareness that the agricultural sector is also a profitable business. Moreover, the positive perception of farmers as a profession also needs to be grown, especially for early age students. This present study was conducted to increase the interest, competence, and entrepreneurial spirit in agriculture through the implementation of agri-food education and agripreneurship. It was a case study, and the participants were 30 students of 5th grader in SD IT Al-Anwar Mojosari. There were three stages involved: 1) Preparation, 2) Implementation of the Program, and 3) Evaluation. For the data collection, a survey was used as an instrument in this study. The results have shown that there were the high enthusiasm and participation of the students during the activities which are indicated the positive effects of the implemented program.
\end{abstract}

Keywords: Agri-food Education, Agripreneurship, Agricultural education, early age

http://dx.doi.org/10.21776/ub.agrise.2021.021.1.5

Received 14 November 2020

Accepted 13 January 2021

Available online 31 January 2021

\section{INTRODUCTION}

Agri-food education is a learning process seen as an effort to realize the importance of the agriculture role in fulfilling the food needs for individuals to meet adequate nutrition for the body, such as protein, carbohydrates, and fats so they can live healthily and productively. On the other hand, agripreneurship is a branch of entrepreneurship that is applied to businesses in the agricultural sector that is manifested by the ability to think creatively, innovatively, visionary, also to communicate, and motivate oneself to take the opportunities in the agricultural sector. Furthermore, agri-food education and agripreneurship are two main components in the human resources development of the agricultural sector which are expected to create added value, sustainable progress, and increase product competitiveness as well as modernize the agricultural sector in a more efficient and sustainable manner.

The reality of agricultural sector development shows that one of the obstacles encountered in the provision of qualified human resources is the stereotype of the agricultural sector itself. Agri-food education and agripreneurship offer paradigm shift opportunities or younger generation perspectives of agriculture so that the younger generation will understand the potential of the agricultural sector

CITATION: Sujarwo, Prasetyaningrum, D., Fajar, Y., Aini, E., Aprilia, A., Setyowati, P., Laili, F., (2021). Agricultural Education: Investing Basic Agri-Food Education and Agripreneurship Knowledge to Early Age Students, 
better and reduce the negative stereotype itself. The agricultural sector that is advanced, modern, and dynamic with both innovation and value creation constructed by the younger generation will provide an exemplary magnitude of the potential of agriculture in Indonesia. Moreover, this potential can be transformed into an income that gives a more decent standard of living.

The youth disinterest in the agricultural sector becomes a phenomenon that has led to the decline of younger generation participation (Klaten, Umrotun, Priyono, Amin, and Aminudin, 2001). The lack of involvement is also affected by the lack of technology use in the agricultural family business, also the low technological changes contribute to the decline of the agricultural sector (Sujarwo, Reed, Saghaian, 2016). Moreover, small-scale enterprises that mostly traditional in production lead to high inefficiencies particularly in production activities (Sujarwo, Reed, Saghaian, 2015). Finally, the farming profitability resulted from agricultural production is getting smaller and less attractive.

The low regeneration in agriculture is a fact. It can be seen from the data of the population employed in the agricultural sector is getting older. There are five groups of factors that influence the decision in moving from agriculture to nonagricultural sectors, namely: (1) the individual characteristics (age, education, experience, gender, marital status, and ethnicity), (2) the characteristics of the family (number of children, age of children, and family size), (3) the characteristics of farming (the size of land tenure, the size of the farm, agricultural output, farming systems, and agricultural productivity), (4) the financial characteristics (income outside of work, agricultural subsidies, social benefits, and unstable income), and (5) the location and characteristics of the labor market (employment rate, access to employment, population density, urbanization, and the location of the area) (Tocco et al., 2012).

In addition to these five factors, the interest owned by an individual also influences the decision making in choosing a business field. Interest is a key aspect of both individual and job compatibility. Interest is usually affected by the environmental background, economic level, social status, and experience (Muawiyah, Sitty. 2014). A strong pull factor of labor mobility in rural to urban areas is the emphasis on the economic development in the industrial sector (Purwatiningsih, 2016). This development has opened many new job opportunities. Meanwhile, the low revenue from agriculture becomes a push factor mobility that gives sizeable influence. This can be seen from the statistics show that the nominal wage rate of agricultural employment continued to rise. However, wages tend to be increased. However, compared to the industry, the increasing rate of agricultural wages is only about half the industrial wages (Kasryno, 2000).

The fundamental changes in socio-economic coupled with the improved transportation facilities to the rural areas are the complementary causes that indirectly created a scarcity of labor in the agricultural sector (Tarigan, 2004). Correspondingly, education produces many educated youth generations but unfortunately, they are not familiar with the agricultural sector. Education tends to create an assumption that agriculture is only suitable for those who are not doing well in school (Prayoga, 2017)

The absence of efforts to introduce agriculture from an early age, the absence of a charge of agriculture, and the importance of agricultural education at primary to secondary level become the pull factors in marginalizing jobs in agriculture. Additionally, the younger generation often saw the agricultural sector in 3D (Dirty, Dangerous, and Difficult) point of view. So, the introduction of agricultural education at an early age become an effort to be an entry point to increase the employment interest in agriculture.

The conducted analysis of the situation and identification of problems in the agricultural sector resulted in one alternative solution described in this study. The solution is an effort in increasing awareness especially in the role of agriculture and its potentials since early ages. It is realized by the implementation of agri-food education and agripreneurship during extracurricular hours in the school of primary and secondary levels. This present study implemented the solution by focusing on primary school students.

By starting to give agricultural and entrepreneurship education at an early age, it is expected to increase the awareness, knowledge, and skills of the students, especially in agriculture. The objective of this study was generally to increase the interest and competence in innovative and creative agriculture through the implementation of agri-food education and agripreneurship from an early age. While the specific objectives of this study were: (1) to increase the agricultural knowledge and understanding of early ages students that are adapted to the Primary Education Curriculum; (2) to foster the entrepreneurial spirit from early ages as a first step in creating a competitive workforce. 


\section{RESEARCH METHODS}

The method in agricultural education through the introduction of agri-food was a series of activities starting firm the land preparation until the postharvest handled directly by the students. These activities aimed to foster and stimulate the interest of the students in agricultural activities. The activities introduced would not only limit to rural but also urban farming. Both types of farming carried out to provide a broader knowledge of agricultural activities only bounded to on-farm activities.

Furthermore, students were introduced to the marketing activities of agricultural commodities that were expected to foster the creativity and innovation of students in grasping the business opportunities on agricultural commodities. The main objective of teaching agripreneurship to the primary students was to encourage and train their way of thinking, decision making, and the development of ideas to catch market opportunities.

This present study conducted a survey to the students for extracting quantitative data derived from the perception of the agricultural sector as well as the knowledge of agricultural technology. The data were analyzed to determine changes in the perception and knowledge of students after doing agri-food education and agripreneurship activities.

This study involved 305 th graders of primary school. The activities in community services were divided into three stages: 1) Preparation, 2) Implementation of the Program, 3) Evaluation.

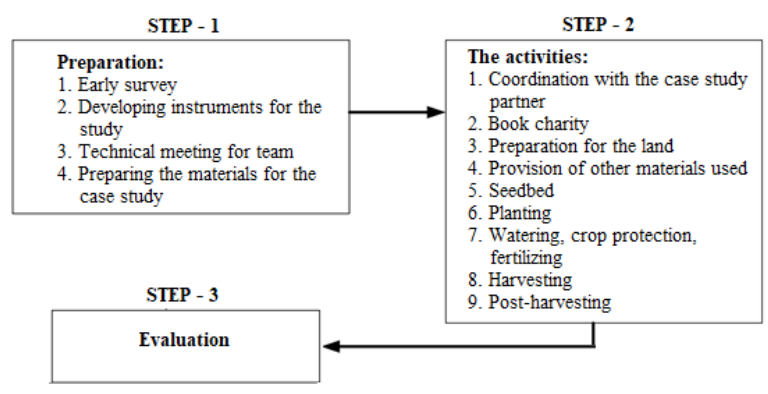

Figure 1. The Implementation Stages of Agriculture Education Case Study in SD IT Al Anwar

\section{RESULTS AND DISCUSSION}

\section{The General Overview of SD IT Al Anwar}

This present study was a case-study located in SD IT Al-Anwar, Mojokerto. SD IT Al-Anwar's missions were to provide the knowledge and introduce not only environment but also agriculture to the early age students. The missions were purposively done to sharpen their creativity and realize the business opportunities, particularly in agriculture.

The vision, missions, and goals of SDIT AlAnwar were as follows:

Vision: Educating the younger generation to has a perfect personality of Moslem and excel in IMTAQ as well as environmental Science and Technology

Missions:

1. Growing and enriching faith

2. Embedding sincere worship and charity

3. Developing creative thinking, remember towards Allah, and skill optimally

4. Creating Adiwiyata school environment that beautiful and comfortable for the students' learning process.

5. Manifesting the institution that:

a. Preserving environmental functions

b. Preventing environmental pollution

c. Preventing the occurrence of environmental damage

Goals:

1. Praying and being humble towards parents, loving cleanliness, and protecting the environment.

2. Al-Anwar graduates can memorize $30 \mathrm{Juz}$ of AlQuran in Tartil

3. Accomplishing achievements in subjects, sports, and art competitions at the sub-district level.

4. Being able to operate the paint program and Microsoft Word.

5. Memorizing surah and daily prayers in Indonesian, Arab, and English

6. Being able to speak English for daily conversation fluently

7. Being able to speak Arabic for daily conversation

8. Being able to practice the basics of raising ducks/chickens

9. Being able to implement the basics of gardening and farming

10. Being able to practice the basics of daily cooking and sewing

11. Guiding, training, and having an entrepreneurial spirit

12. Making SD IT Al-Anwar a model school that is loved by the community

13. Having a high commitment to lifelong learning. Defending religion and nation.

14. Realizing a clean, green, beautiful school environment that provides comfort in learning

SD IT Al-Anwar had sought to achieve agricultural education from an early age to their students by providing access for stakeholders, students, and NGOs for cooperation and training. However, the activities were sustainable due to the program offered for the short term. Such activities were only in the range of planting 
activities or the creation of creative products. More agriculture educational activities had never been provided especially starting from upstream to downstream activities such as marketing and management activities. Another challenge faced by SD IT Al-Anwar was the low participation of the students in these activities.

\section{Agri-food Education Design}

It began with socialization conducted offline by keeping the health protocol in the covid-19 era. The participants were 5th graders of SDIT Al Anwar. The socialization carried several objectives: (1) Provided basic knowledge related to agriculture cultivation, planting technology, as well as other potential aspects of the agricultural sector, (2) Got some feedbacks to describe the knowledge of 5thgrader agriculture. This activity was carried out for \pm 60 minutes including 15 minutes for the students to fill out the questionnaire to measure the agricultural knowledge of the students and 45 minutes for introduction including the explanation about urban and rural farming.

Agri-food Education fundamentally emphasized the introduction of a mechanism in agriculture activities at an early age that focused on the pleasant atmosphere and practice-based learning. In providing a learning mechanism suitable for the early age students (5th grader), the learning modules were designed based on the development of the 5 th grader's characters. The learning modules prepared using simple language and visuals so that they could easily grasp the information given. Also, the learning modules served as guidance to the students in studying the agricultural production activities. Agri-food education started with the socialization of agri-food in SD IT Al-Anwar. The socialization aimed to provide an overview of how agri-food education would be implemented. The documentation of the activities as follows:
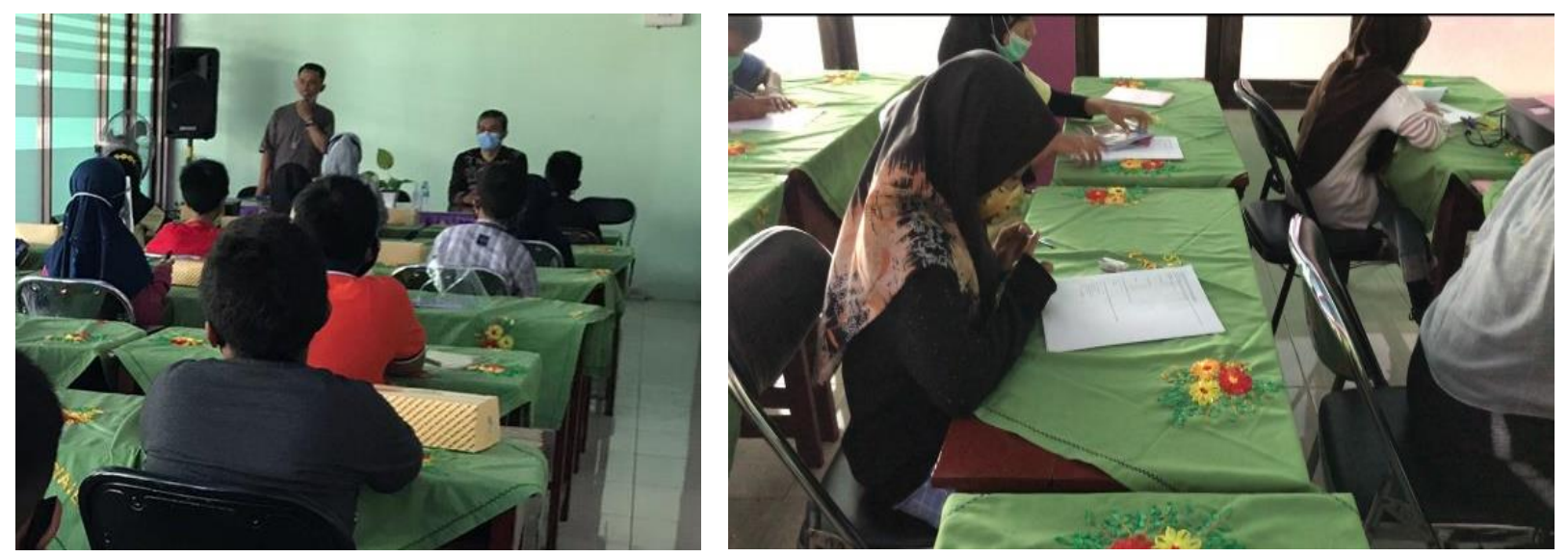

Figure 2. The Socialization of Agri-food Education to the Students of SD IT Al-Anwar

After finishing the socialization, the preparation needed to provide experiences for the students in the preparation of both planting and cultivation. These activities were implemented directly by the students to give a pleasant experience in agricultural production. Here is the documentation of the activities:
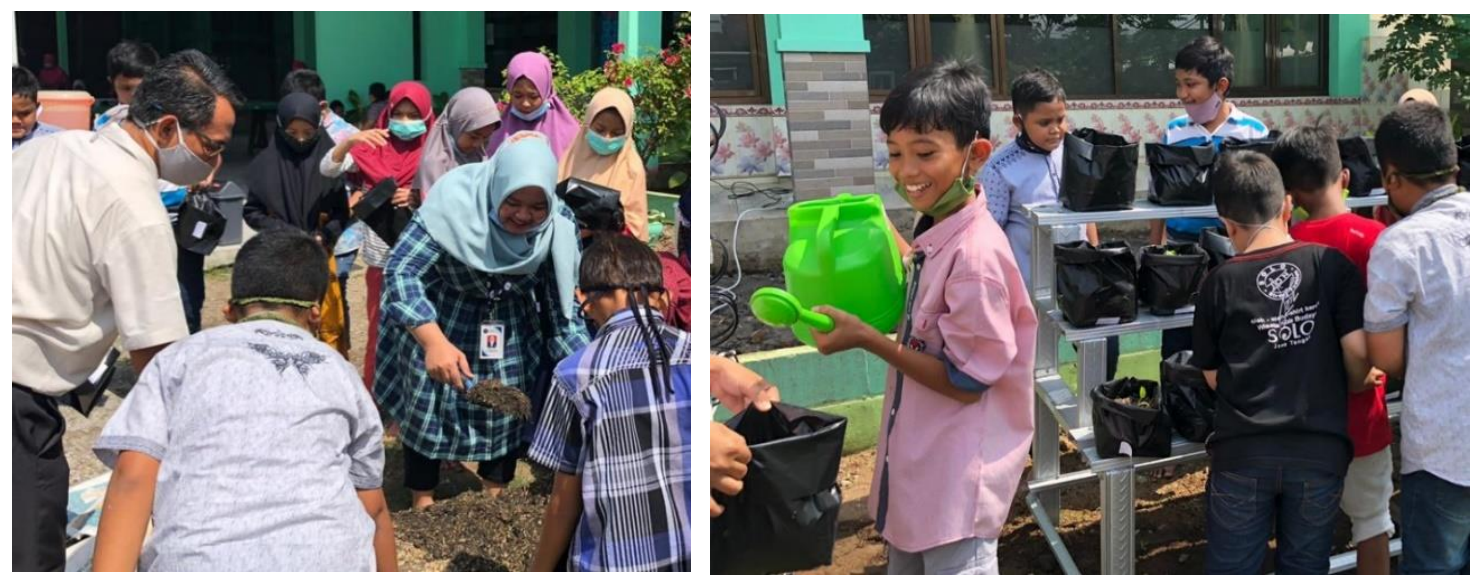

Figure 3. The Planting Preparation with the Students of SD IT Al-Anwar 
The next activity in agri-food education was planting with students. The seasonal vegetable crop grew in both soil and without soil planting medium, namely hydroponic. Various production technologies were introduced to provide many positive, creative, and pleasant activities so that the positive effects were not only gained in the knowledge but also the skills of the students. Moreover, the variety of activities provided also useful for stress releasing due to online learning during pandemic Covid-19. The documentation of the activities as follows:
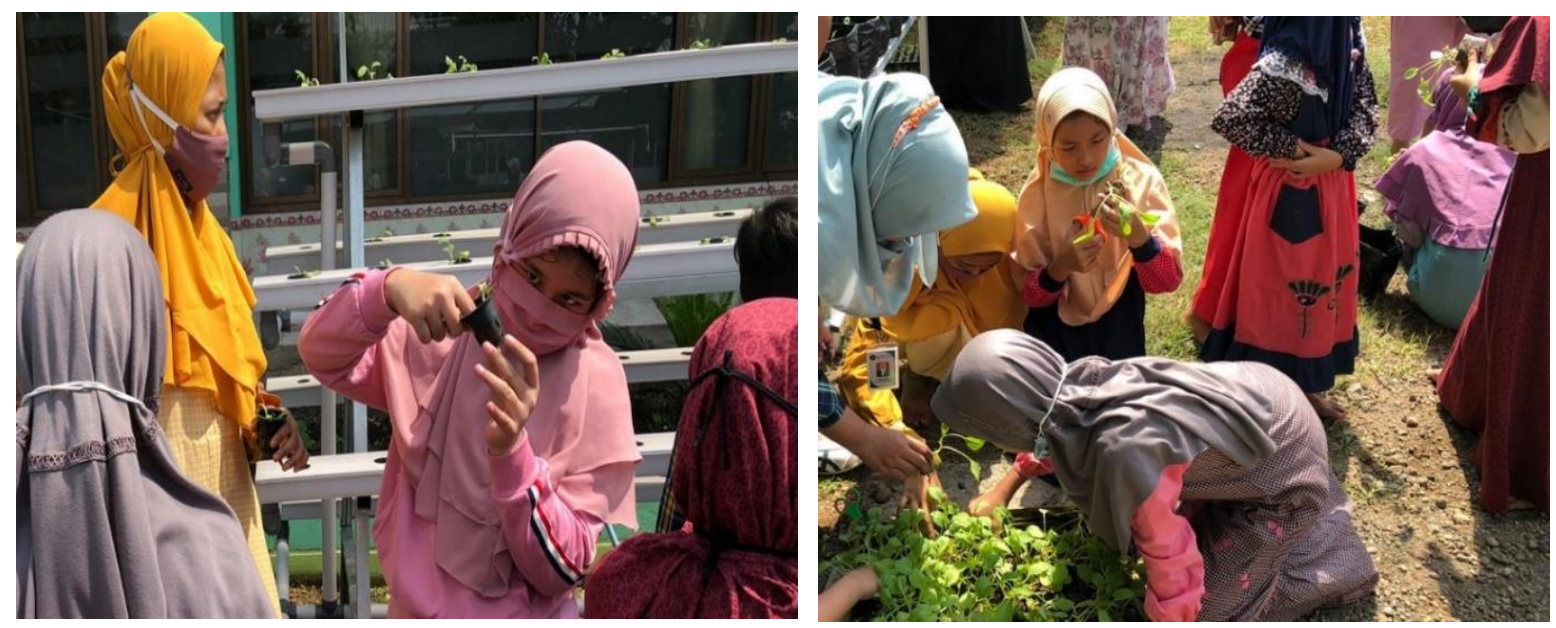

Figure 4. The Planting Preparation with the Students of SD IT Al- Anwar

\section{Agripreneurship Design}

There were two kinds of main activities carried out in this study: introducing Agri-food Education and Agripreneurship to the students of SD IT Al-Anwar. Agripreneurship was defined as a growth stimulation mechanism of the entrepreneurial spirit in students mainly related to the efforts in the agricultural sector. Both terms, Agri-food education and Agripreneurship, were placed on integrated activities with each other. Agricultural activities carried out by the student were fundamentally environmental and sustainable based agriculture or known as healthy and sustainable agriculture.

The development of agripreneurship in SD IT Al-Anwar was done by giving opportunities to the students to harvest the agricultural products which grew from soil or hydroponic. Then, they also packed the product then marketed it. The harvesting and packaging process of the product was accompanied by a team involved in this program. Furthermore, the selling and marketing products were done independently by each student.

\section{The Perception of The Students on Agriculture}

After the socialization and implementation, the data collection was done to measure the perception of the students towards agriculture. Here were the results of the data analysis from the initial survey taken from the students of SD IT Al-Anwar. The survey asked about the perception of the view of agriculture, the knowledge related to the planting medium, agricultural commodities, technology in agricultural production, sequences of agricultural activities, processed agricultural commodities, marketing, and farmers as a profession. The data revealed that the high level of agricultural knowledge showed by $17 \%$ (5 students), medium level showed by $33 \%$ students (10 students), and low level showed by $50 \%$ (15 students. 


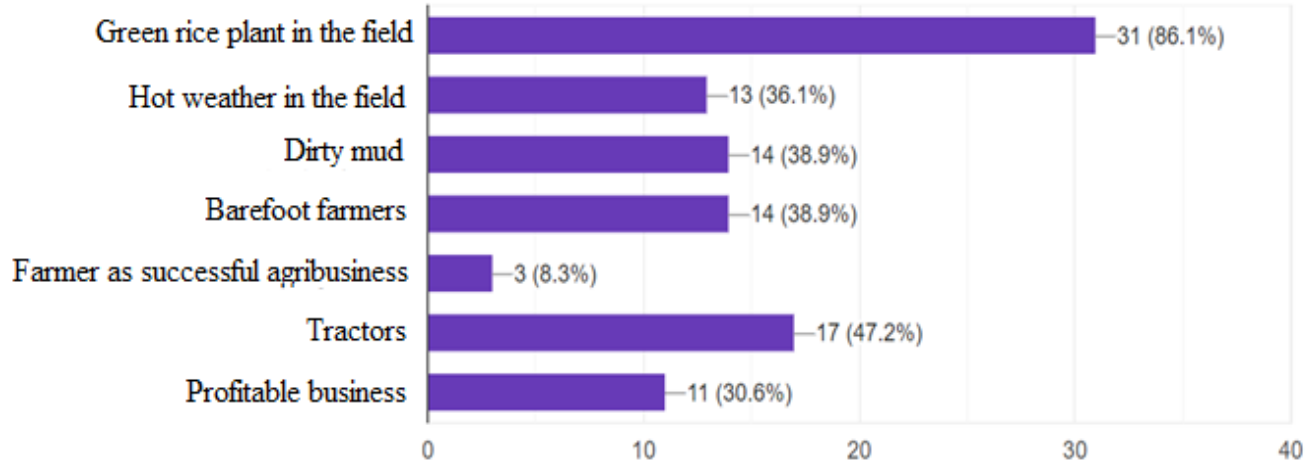

Figure 5. The Distribution of The SDIT Al Anwar Students' Perception on Agriculture in

(Source: Primary Data Processed, 2020)

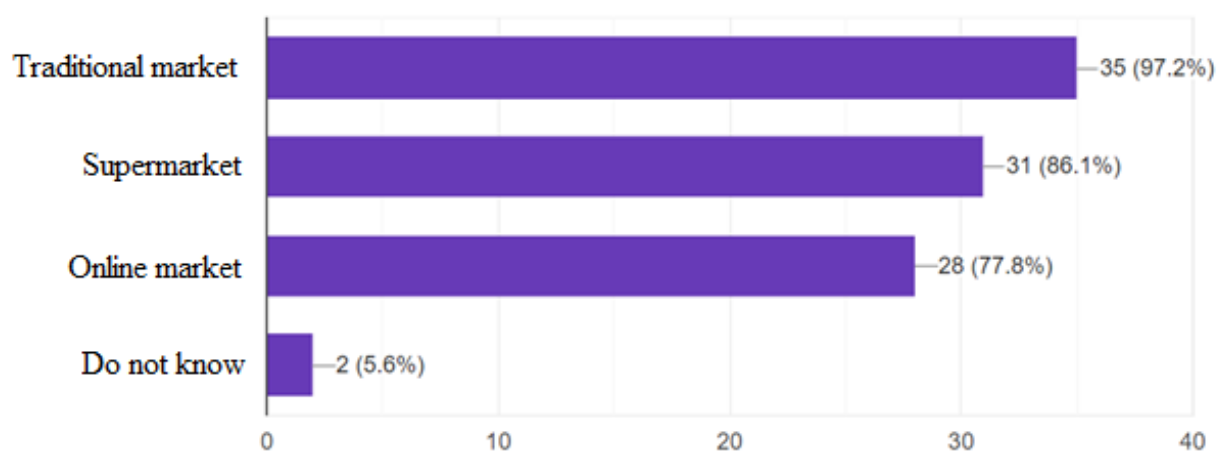

Figure 6. The Distribution of The SDIT Al Anwar Students' Perception on Agricultural Products Marketing (Source: Primary Data Processed, 2020)
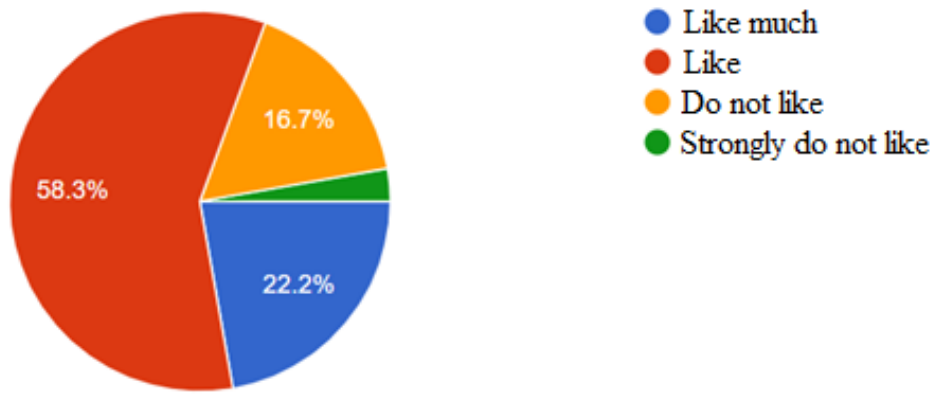

Figure 7. The Distribution of The SDIT Al Anwar Students' Perception on Business Preferences (Source: Primary Data Processed, 2020)

The measurement results through this survey showed the students of SD IT Al-Anwar perception of the agricultural sector was still not so encouraging. The agricultural sector was considered as a sector that provided soothing scenery with green land, but not yet a profitable sector. It was apparent from the perception of the students towards farmers as a profession as well as a profitable business was relatively very low, which each only had three students and 11 students of the total 103 students.

There was diversification attention on product marketing, although the traditional market was still dominant. However, the data showed that they started to pay attention to marketing agricultural products to supermarkets and online marketplace. While from the perception of the business preference level in agriculture displayed a portion of $22.2 \%$. It indicated good potential by remembering that the perception of the agricultural sector was in demand by the students. 


\section{CONCLUSION}

Agri-food education activities and agripreneurship development of SD IT Al-Anwar students show a positive effect qualitatively in constructing awareness and spirit of the younger generation to make the agricultural sector as an alternative for the development of a profitable business. Efforts to grow awareness and enthusiasm in doing business in the agricultural sector are required early and taught with a series of fun practice-based activities.

SD IT Al-Anwar students feel the positive influence in agricultural education through agrifood education and agripreneurship by demonstrating their high participation and enthusiasm in carrying out the activities programmed. The headmaster of SD IT Al-Anwar is also very supportive of the program so that this positive effect will certainly bring the best results in the implementation of agri-food education and agripreneurship.

\section{ACKNOWLEDGEMENTS}

We would like to thanks to University of Brawijaya in funding this case study and all the School Board and students of SD IT Al-Anwar, Mojokerta which give us the opportunity in conducting this study.

\section{REFERENCES}

Kasryno, F. (2000). Sumber daya manusia dan pengelolaan lahan pertanian di pedesaan indonesia. Fae, 18, 25-51.

Klaten, k., umrotun, priyono, amin, c., \& aminudin, M. Farid. (2001). Pemuda dalam sektor pertanian stud i kasus di desa delanggu kecamatan delanggu kabupaten klaten. Forum geografi, 15(2), 193-218.

Muawiyah, Sitty. (2014). Faktor - Faktor Yang Mempengaruhi Minat Petani Berusahatani Padi Di Desa

Sendongan Kecamatan Kakas. Jurnal Penelitian Sosial Ekonomi. Fakultas Pertanian Universitas

Sam Ratulangi Manado. ManadoPrayoga, k. (2017). Pergeseran preferensi dan kesempatan kerja pemuda desa di sektor pertanian. In seminar nasional pembangunan ii (pp. 199-201).

Purwatiningsih, s. (2016). Respons anak-anak migran terhadap migrasi internasional di perdesaan ponorogo. Populasi, 24, 57-71.

Sujarwo, Michael R. Reed, Sayyed H. Saghaian. (2015). Production Effficiency of SmallScale Shallot Producers in East Java, Indonesia. Journal of Global Economics, Management, and Business Research. Vol. 2 (Issue 2): 59-71

Sujarwo, Michael R. Reed, Sayyed H. Saghaian. (2016). Changing Technical, Allocative, and Economic Production Efficiency of SmallScale Farmers in Indonesia: The Case of Shallot Production. Journal of International Agricultural Trade and Development. ISSN: 1556-8520. Vol. 10 (Number 1): 31-51

Tarigan, h. (2004). Representasi pemuda pedesaan mengenai pekerjaan pertanian: kasus pada komunitas perkebunan teh rakyat di jawa barat, (29), 1-19.

Tocco, b., davidova, s., bailey, a., tocco, b., davidova, s., \& bailey, a. (2012). Labour adjustments in agriculture: evidence from romania labour adjustments in agriculture: evidence from. Studies in agricultural economics, 116, 67-73. 
This page is intentionally left blank 